\title{
活性合金化法によるセラミック・シール技術
}

\author{
室 松 剛 雄・荻 野 秀 雄 - 吉哥岡 利一* \\ (昭和 36 年 2 月 8 日 受理)

\section{Ceramic-to-Metal Seals by Reactive Alloying Method} \\ Tatuo MUROMATU, Hideo OGINO and Tosikazu YOSIOKA
}

(Electrical Communication Lab., Nippon Telegraph and Telephone Public Corp.)

\section{1. まえがき}

ここ数年の間に、真空管の分野ではセラミック・シー ル化が急速に進展し(1)、はじめ汸ラライトロンや大型 送信管等に多く見受けられたセラミック管が受信管の分 野にも現われ、トランジスタに対抗する $\mathrm{R} ・ \mathrm{C} ・ \mathrm{~A}$ 社の 超小型管や、あるいは $\mathrm{G} \cdot \mathrm{E}$ 社の $\mathrm{TIMM}^{(2)}$ と称する抵 抗・容量をも内臟しそれ自体で回路を構成した双 3 極管 のマイクロモヂュールの一種まで報道され、永い伝統を 持つガラス・シール真空管に置きかわり、限界に達してい た真空管の性能を飛躍させ、今後どれほどの発展を見せ るか大きな期待の寄せられる状況にあるが、これらはセ ラミック真空管が 1) 耐熱性がきわめて高い。したが って排気時高温にあげることによって、非常に真空度の 高い真空管が得られる。これは真空管の高性能化・長寿 命化・高信頼化を約束することとなり、又、同一性能なら ば小型化・同一寸法ならば高出力化の設計が可能とな る。 2) セラミック部品は精密加工ができ、またその 寸法の維持性が良いので寸法精度の高い真空管を作り得 る。 3）セラミックの機械的強度が優れているので、 耐震耐衝撃性等の高い真空管が作られる。4）セラミッ ク法高周波損失・絶縁耐力等の電気的特性が良いため に、優れた高周波用あるいは高圧用電子管が得られる。

5）セラミックは放射線に強い。乙れは宇宙㧍よび原 子力関係に秃いて有用となる。等、数々の優れた特色を 持つことによるものである。またこのようなセラミック ・シールは、シリコン・ダイオード等の半導体部品をは じめ、コンデンサー・トランス類のハーメチック・シー ル部品からダイアモンド・ッールのごとき加工具への応 用、ジェットェンジンやロケットへの応用等に至る打よ そ非金属材料と金属との強固な接着が望まれる広い分野 にわたってその価值を発揮しつつあり、真空機械にも、

\footnotetext{
* 電気通信研究所
}

最近超高真空用の実用ポンプとして注目を浴びている放 電型バッター・イオン・ポンプのリード封入に適用さ れ、その性能に重要な貢献をしていることはすでに知ら れているところであろう。

セラミックと金属を接着させようとする試みはかなり 昔から多種多様な方法で行われているが、真空気密性泥 保証したいわゆるせラミック・シールが実用に具体化さ れたのは、第 2 次大戦中の独乙における超高周波管で、 戦後研究がアメリカに引継がれ今日の発展を見るに至っ た。今日実用的に定着したと見られるシール技術には、 歴史的に古いモリブデン (Mo) ・メタライズ法と活性 金属法の 2 系統があって、夫々の特色を持って居り、シ 一ルの対象によって何れかが選択されるべきものとい党 よう。ここでは、はじめに現在広く実用されている技術 の概略を述べ、主としてわれわれの取扱ったチタン (Ti $)$ ーニッケル $(\mathrm{Ni})$ 活性合金法によるチタンーフル ミナ $\left(\mathrm{Al}_{2} \mathrm{O}_{3}\right)$ の板封じ技術を御紹介するとととした い。もとよりとれはシール技術の一例を示寸ものに過ぎ ないが、これによってセラミック・シールの技術的性質 とその性能について、いささかなりとも理解をいただけ れば望外の幸である。

\section{Mo メタライズ}

Mo メタライズ法は、Telefunken で創始された Mo 粉末に $\mathrm{Fe}, \mathrm{Ni}$ を加えてこれをセラミックにシンター する方法（いわゆる Telefunken 法）に始ったが品質 のコントロールが難かしく技術が充分に定着するに至ら なかった。戦後これが米国に引継がれ、Nolte \& Spurck により $\mathrm{Fe}, \mathrm{Ni}$ の代りに Mnを入れていわゆる Mo-Mn: 法 $^{(3)(4)(5)(6)(7)}$ 飞改良され、今日もっとも典型的なメ夕 ライズ法として発達した。これはセラミック部品の封着 部に Mo 粉末を焼結して金属表面層を形成し、これを他 の金属または同様に処理したセラミックに鏝付けしてい 


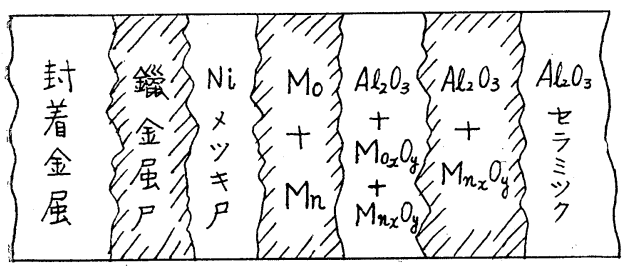

第1図 Mo-Mnメタライズ法による封着機構

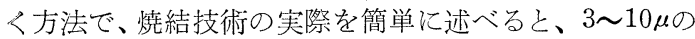
Mo粉末に 10〜20\% の Mn 粉末を加党、例壳ば醮酸ブ チル・ニトロセルローズ等からなる適当な有機溶剤に溶

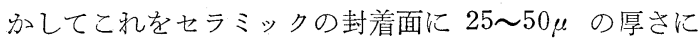
塗付・吹付けなどの方法で被覆する。このものを40〜 $60^{\circ} \mathrm{C}$ の飽和水蒸気を含有した水素 $\left(\mathrm{H}_{2}\right)$ 䨌囲気中で加 熱する。温度はセラミックの種類や Mo ペーストの内 容によって左右されるが $1300 \sim 1500^{\circ} \mathrm{C}$ で通常 30 分程度 加熱する。かくして得られる生成面は第 1 図のメッキ層 までに示されるごときもので、条件が整えばかなりの磨 耗抵抗を持った滑らかな金属光沢面が得られるといわれ ている。Mn の役割は、セラミックへの拡散性が高く Mo を強く結合させるなかだちとなるところにあり、ひ いては焼結に要する温度が低くなるが、Mo の粒度が $1 \mu$ 程度に細かくなればその必要はなく、むしろ Mnの ない方が封着強度の高いメタライズ面が得られるという 報告 ${ }^{(6)}$ もある。バインダー溶液としては適当な粘度・炭 素の残留が少ないこと・適当な乾燥速度を持つことなど が重要であり、また金属粉末を十分に分散させる万法が 問題となろう(6)。 $\mathrm{H}_{2}$ 雾気中の水分は、MoおよびMnを 結合に必要な酸化物の形にするために必要であり、一方 仕上り表面辻分に金属性であることが望まれるので、 雰囲気のコントロールは極めて重要な問題である。上の ようにして得られた面に、普通 Niメッキを行い、これを 水素中で加熱し拡散処理を施せば、後は通常の金属対金 属の鑞付技術と全く同様に他の部品と気密鑞付けするこ とができる。すなわちこの方法は七ラミック部品の封着 部を予め金属化する技術に焦点があり、工程は高温作業 を含み多段であるが、その後の操作は従来の臘付技術と 変りがなく、目的に応じて鉛半田鑞のごとき低温鑞から 銀鑞のごとき高温鑞に至るまで鑞材料を自由に選択しう る特徵がある。

\section{3. 活性合金法}

1947年 G・E社の Bondley ${ }^{(8)}$ が、活性金属である Ti の親和力を利用し金属を直接セラミックに封着させ る方法を発表した。これは 300 メッシュ程度の $\mathrm{TiH}_{2}$ 粉

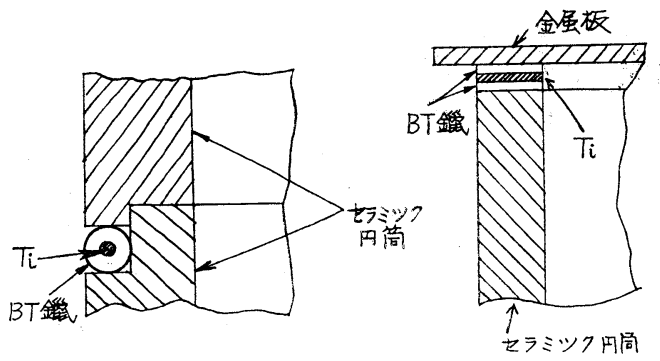

第 2 図 Ti-BT 鑞によるシール法の例

末をニトロセルローズ・ラッカーのごとき溶剤に溶かし てペイントを作り、こ礼をセラミック面に塗付し、被封 着金属との間に適当な形状の純銀または銀一銅共晶合 金等の鑞金属を挿入乙、真空か清浄な不活性ガス中で 900〜 $1000^{\circ} \mathrm{C}$ に加熱することによって封着が行われる。 この方法は一操作で強力な bond が得られる有効な技術 であるが、鑞の流れが良すぎることと一様な $\mathrm{TiH}_{2}$ ペイ ントの被覆を得るのに熟練を要するといわれている。

上の加熱工程で $\mathrm{TiH}_{2}$ が約 $650^{\circ} \mathrm{C}$ で分解し、その時発 生した原子状の活性水素が被封着部品の表面を清浄にす ることにより bond が有効に行われることが指摘された が、M・I・Tの Pearsall とZingeser ${ }^{9)}$ が活性金属 としてさらにデルコニウム $(\mathrm{Zr})$ ，タンタル $(\mathrm{Ta})$ 等に ついて研究を行った過程で、水素の存在が必要でなく、 これら活性金属と銀 $(\mathrm{Ag})$, アルミニウム (Al) 等の 合金によっても良好な封着ができることを発見し活性合 金法のさきがけとなった。この活性合金法は、Ti と $\mathrm{Ag}$

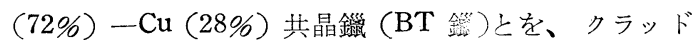
した bond用鑞材の形で使用することにより実用的に確 立された ${ }^{(10)(11)(12)}$ 。すなわち重量比で 5 〜 10\%の Ti を 上記 BT鑞 でクラッドした 0.05〜0.1mm の線またはリ ボン状のものを第 2 図のように封着せんとする部品間に 装着し $10^{-4} \mathrm{mmHg}$ 以上の高真空中または良く乾燥した


はセラミックに予め何等の工作も加えず、ステップで操 作が完了する極めて有効なシール法であり、生成する $\mathrm{Ti}-\mathrm{Ag}-\mathrm{Cu}$ 合金鑞もセラミックとの濡孔が良く、強い bond を実現しうる点で非常に優れたものである。し かし先のメタライズ法に比較すると封着温度が固定して おり、かつ高温であるために封着条件の制約が大きくな る。また生成鑞の流れが良すぎるのでそのコントロール に注意することと、比較的に蒸気压の高い $\mathrm{Ag}$ を成分と しているので封着作業時及封着部品の使用条件に配慮が 必要である。

この $\mathrm{Ag}$ を含まず、 $\mathrm{Ni} や \mathrm{Cu}$ との合金化による新しい 活性合金化封着法が 1956年 G・E社の J ・ E. Beggs ${ }^{(13)}$ 


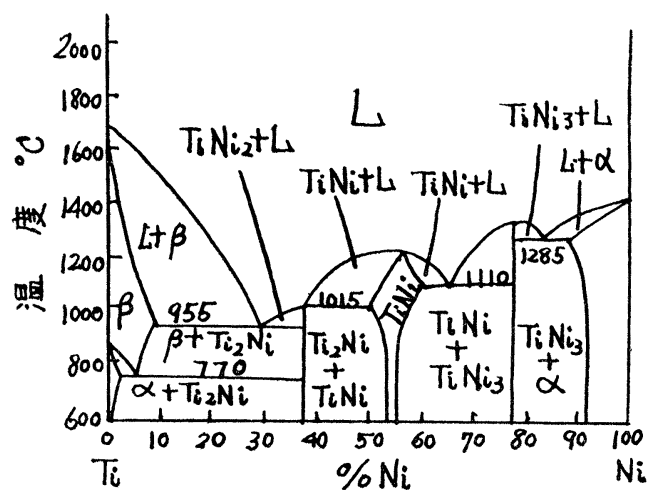

第 3 図 $\mathrm{Ti}-\mathrm{Ni}$ 合金状態図

第 1 表 上着用活性合金の種類とその封着温度,なら びにそれに適するセラミック

\begin{tabular}{|c|c|c|c|c|}
\hline $\begin{array}{l}\text { 活性合金の } \\
\text { 種類 }\end{array}$ & $\begin{array}{l}\text { 最低封产 } \\
\text { 愠度 }{ }^{\circ} \mathrm{C}\end{array}$ & $\begin{array}{l}\text { 最高封着 } \\
\text { 温度 }{ }^{\circ} \mathrm{C}\end{array}$ & \multicolumn{2}{|c|}{ 封着用セラミック } \\
\hline $\mathrm{Ti}-\mathrm{Cu}$ & 875 & 910 & Alumin & , Forsterite \\
\hline $\mathrm{Ti}-\mathrm{Ni}$ & 955 & 1050 & " & " \\
\hline $\mathrm{Zr}-\mathrm{Cu}$ & 885 & 910 & $"$ & " \\
\hline $\mathrm{Zr}-\mathrm{Ni}$ & 960 & 1050 & Alumin & , Zircon \\
\hline $\mathrm{Zr}-\mathrm{Fe}$ & 934 & 1015 & $"$ & $"$ \\
\hline
\end{tabular}

によって発表された。第 3 図は Ti一 $\mathrm{Ni}$ 合金の状態困 ${ }^{(14)}$ (15)であるが、N128\%の所融点の最も低い一つの共晶 点が見られる。したがってての成分比の合金を $955^{\circ} \mathrm{C}$ 以 上に加熱すると熔融し、このような液相状態にある $\mathrm{Ti}$ が七ラミノクに触れるようにすると、とれと反応して気 密に結合される。第 1 表は、かような活性合金の種類と その封着温度およびそれに適したセラミンクをあげた もので岁る。これらによる封着では、その封着作業時 および封着温度まての使用条件で金属の䄈気圧は $10^{-6}$ $\mathrm{mmHg}$ 以下に保たれる。活性金属の種類はこの他にも あけられるが、要は活性金属元素が液相でセラミックに 接触することによって封着が達成されることにあり、そ の機構はいまた明確に说明されていない。かような合金 類は一般に脆く硬いためにこれを線や箔の形状にして通 常の鑞仏のごとく使用することはできないので、各成分 金属をンム（shim）にし封着操作の過程で合金化する 方法が取られている。われわれは、第 4 図(a)のような 部品を同区 (b)のごとく、 $\mathrm{T} 1$ 板とセラミックの閒に Ni 簿を㨂入し適当な荷重を加えてこれらを緊密に按触さ せ、高周波加熱で被封者金属て西る $\mathrm{T} 1$ 板を值接加熱す ることにより T1 とヒラミ, クの板封じ技術の開発を行 ったので、こ秃に基ずき活性合金法についてやや詳しর 述べることとしたい。

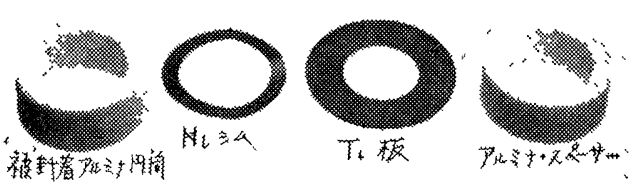

第 4 図（a）封着用部品



第 4 図（b）封着のためのセット

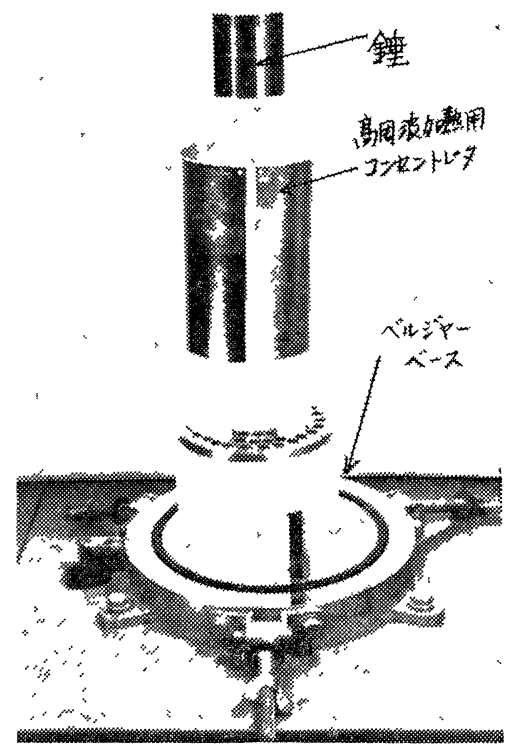

第 4 図（c）同上の写真

\section{Ti-Ni 活性合金法}

まず上記のような状態にして加熱した場合、温度の上 昇とともに $\mathrm{Ti} \rightleftarrows \mathrm{Ni}$ 回摭散：Ti-Ni の合金液化：熔 融合金とセラミッタの bond現像が相連続して生起する 


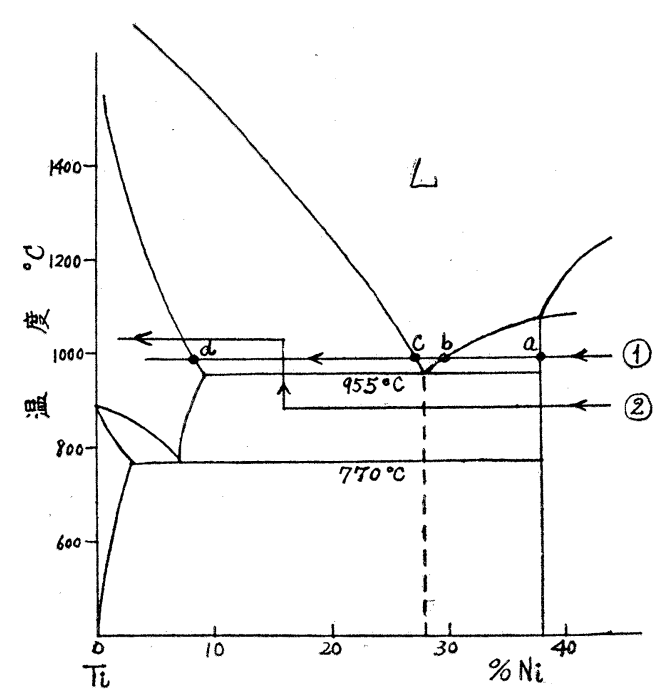

第 5 図 加熱操作に伴う現像の説明図

こととなるが、これを第 5 四のように状態図の一部をか り、この上に操作温度線を重礼て考えて見れば、(1)のご とく $955^{\circ} \mathrm{C}$ より少し高い温度に加熱して維持すると $\mathrm{Ni}$ 箔中に次第に Ti が拡散してきて Ni の\%が減少する。 すなわち、線上を左方へ進行し (a)点に至ると (b) 点に相 当する成分の液化がはじまり、(b)点に至ると全部が液化 し(c) 点まで液化状態が継続し、(C) に至ると一部固化が はじまり時間とともに凝固していくこととなる。955 $\mathrm{C}$ より低い温度で加熱し続ける時はも台るえ液化すること なく左方へ進行し、Ti rich の状態となって終ることと なる。また(2)のごとさ加熱操作を行って一旦共晶点を通 り過ぎれば、たとえ $1000^{\circ} \mathrm{C}$ 温度をあげても極少量の 液化しか起らず封着不良となるであるう。不幸にして、

$\mathrm{Ti} \mathrm{Ni}$ 単体が相接している場合の拡散係数值につい ての研究はいまだ見当らないので、拡散の進行を近似的 にも定量的には予測することができないが、その現象は 温度と時間によって定まり、上の図で線上の移動速度は 温度によって変化するので、同一の液化状態を実現する にも温度一時間について無数の加熱コースが存在するこ とになる。とりわけ温度は拡散係数 $D=A \exp -\varepsilon / k T$ の 形でわかるようにきびしく効いてくる。もとよりかよう な状態図は静的平衡条件での相変化を示すものであるか ら、封着のごとき動的な加熱現象飞厳密に当はまるもの ではなく、 $\mathrm{Ni}$ 箔中の $\mathrm{Ti}$ 濃度も分布していて一様には 変化しないが現象の定性的な議論には十分に役立つもの である。加熱操作としては(1)のごときコースを取るのが 望ましいが、実際技術としては、部品のガス抜きのため の加熱行程 : 温度分布の平衡化を図るための加熱操 作：セラミックヘの熱衝撃を考慮した加熱操作等が問

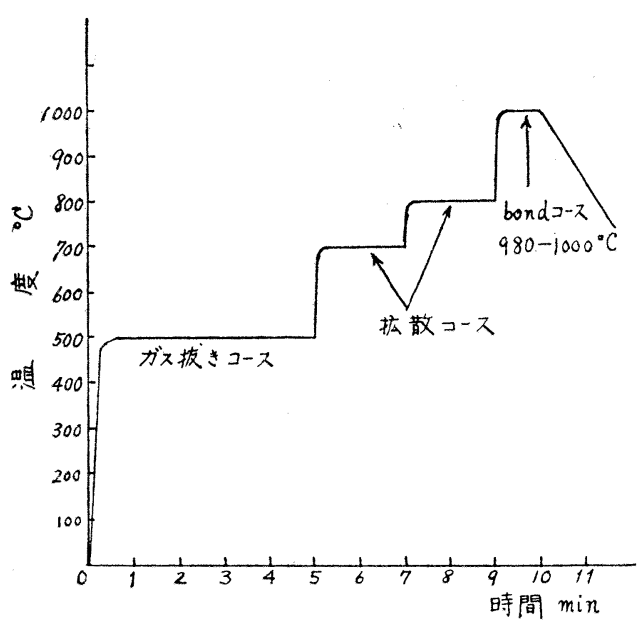

第 6 図 封着温度コース

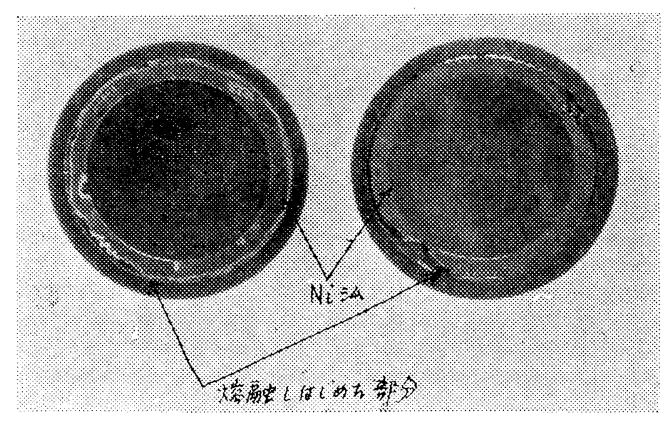

第7図 $\mathrm{Ti}$ が $\mathrm{Ni}$ 箔中に十分に扒散しまさに熔融 しはじめた状態

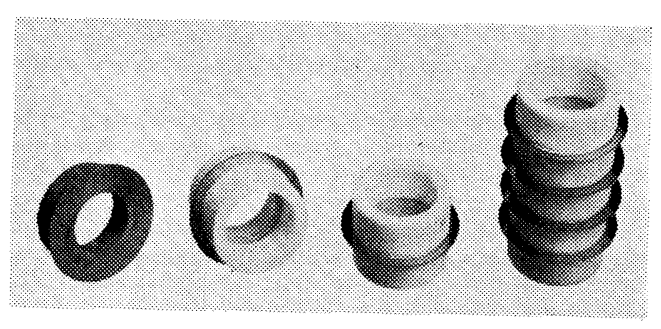

第 8 図封着部品の例

題となり、かような高温えの一ステップ操作は恐らく実 行しがたいものであろう。

われわれは、第 4 図の場合に対し実験的に第 6 図のご とき加熱操作曲線を得た。 $\mathrm{Ni}$ 箔の厚さは $1 / 100 \mathrm{~mm}$ の 場合で $700^{\circ} \mathrm{C}$ 程度から拡散の進行が顕著となってく る。拡散コース以上での温度偏差は $10^{\circ} \mathrm{C}$ 程度以下に抑 えることが望まれる。Tiの拡散が十分な量に達し、ま さに熔融しはじめた状況を第 7 図に、封着された部品例 を第 8 図に示した。 
次に封着に対する諸影響因子について述べると、

\section{a) 温度操作に関連するもの}

封着が理想的に達成されるためには、封着面の全面に わたって上に述べた拡散一熔融一bond 現象が一様に進 行することが必要である。すなわち加熱伴う温度分布 の一様性が重要で、そのためには面の接触条件を支配す るセラミック面の仕上り精度が問題となってくる。かよ うな場合の熱的接触抵抗を定めるものは面の粗さ之平坦 度であるが、われわれのような加熱方法を採る場合は熱 の流入出条件から見てかなり要求がきびしくなり、粗さ が $4 \sim 8 \mu$ 、平坦度は円周ならびに半径方向で偏差 $2 \mu$ 以 下であるものが $100 \%$ の封着率を保証し得た。粗さ法む しろ適度に粗い方が有効で、いたずらに平滑で平坦度が こ我に伴わない特虫最悪の結果它招くであるう。 $\mathrm{Ti}$ 板 の寸法精度には特別な高さを必要とせず， $0.2 \sim 0.3 \mathrm{~mm}$ の厚さではある程度のそりがあっても加熱行程で整形さ れるので差支えない。接触加圧は大きい程良好であるが 実際問題として余り大きな圧力を加觉る方法が問題とな 万う。わ和秃社一応 $400 \mathrm{~g} / \mathrm{cm}^{2}$ の重力荷重を主汇適 用した。

\section{(b) bond 現象に関連するもの}

セラミック素材の組成や焼成温度が、 bond の際の結 合力に影響することはその反応内容吕ら予想されるとこ ろであり、アルミナについてフラックス含有量拉よび焼 成温度の増加とともにシール強度が增加するという報 告(16)が見受けられる。しかし前記 Ti-BT 法を含めて この活性合金法では、あら汤るセラミックと先の差が意 浅さ机ないほど良く結合するものである。

セラミックの前处理として酸洗を行うことは、面を活



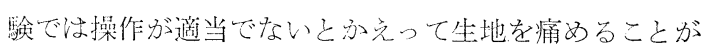
品りこの処理は必要でなかった。これら部品の封着前の

第2.表 封着用部品の処理例

\begin{tabular}{|c|c|c|}
\hline 部 品 & 工程順序 & 工 程 内 容 \\
\hline \multirow{3}{*}{ セラミック } & 1. 脱脂洗滌 & 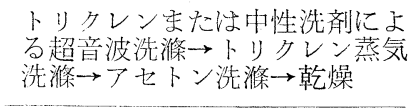 \\
\hline & 2. air oven & 電気炉 $1100^{\circ} \mathrm{C}, 40^{\mathrm{min}}$ \\
\hline & 3. 真空処理 & $10^{-5} \sim 10^{-{ }^{\circ}} \mathrm{mmHg}, 1100^{\circ} \mathrm{C}, 10^{\mathrm{min}}$ \\
\hline \multirow{2}{*}{$\mathrm{Ti}$ 板 } & 1. 脱脂洗滌 & 上に同じ \\
\hline & 2. 真空処理 & $10^{-5} \sim 10^{-6} \mathrm{mmHg}, 800^{\circ} \mathrm{C}, 10^{\mathrm{min}}$ \\
\hline \multirow{2}{*}{$\mathrm{Ni}$ シム } & 1. 脱脂洗滌 & 上に同じ \\
\hline &  & $900^{\circ} \mathrm{C}, 10^{\mathrm{min}}$, Dew Point $<-40^{\circ} \mathrm{C}$ \\
\hline
\end{tabular}

処理例をまとめて第 2 表に示してある。処理後の部品の 污染汇対する注意は、一般真空技術におけると同様の慎 重さを以てすればよく $\mathrm{H}_{2} \mathrm{O}$ vapour による污染に特に 注意する必要がある。

Ti の品質は>99.7\% といわれるもので十分であり、 $\mathrm{Ni}$ は真空管用材質のものをわれわれは使用した。Ni シ ムは厚いほど生成鐦量が多く操作が楽にはなるが、機械 的性質の悪い鑖層の存在が多くなることは封着率や封着 体の強度を損ずることになるので好ましくなく 1/100〜 1.5/100 mm が適量であろう。

活性金属法で法その活性金属の活性度を損じないよう にするととが大切であり、われわれは封着をもっぱら真 空下で行ったが、良く乾燥した稀ガス中でも実施され水 素中で行う例 ${ }^{(18)}$ もる。真空度は $10^{-4} \mathrm{mmHg}$ 以下であ ればよい。

かようにして封着された部品には、何等の蒸発物とく に金属性の蒸着被膜を認めることはなく、その絶縁抵抗 は無限大で、以後の加熱取扱にも $1000^{\circ} \mathrm{C}$ 程度の高温宋 で真空気密性の破壞とか蒸発物を生ずることがなく、一 ステップで封着が行われるととともにこの方法の最も 大きな利点となっている。この技術は前記 $\mathrm{Ti}-\mathrm{BT}$ 法と 同様に封着温度に制約が出り、さらに、それよりも50〜 $100^{\circ} \mathrm{C}$ 高くなる。

また生成合金鑞の展性も劣るので、後述する発生封着 応力は Ti-BT法によるものより大きくなりがちとい党 よう。生成鑞の流動性は $\mathrm{Ti}-\mathrm{Ni} よ り も \mathrm{Ti}-\mathrm{Cu}$ の場合 の方が良いがいずれも Ti-BT 法に比べれば劣ること は免れない。これはこの方法の短所でも㐫り、また長所 ともなる。

これまでに述べた技術的性格から、本方法はわれわれ の取扱ったような突合はせ形態のシールに最も適してお り、その他の形態や大型のものに対しては難かしさがあ ることが理解されよう。

\section{5. 封着応力}

とれまで論じてきたことは、シール技術のうち化学的 内容に属する bond 現象安でであって、適切に行われた シールではアルミナの場合でも bond層の強度はフルミ ナの強度と等価またはこれを上廻るものである。しかし ながら bond が理想的に行われたとしても、その封着 体が気密性を保って歩止るか否かはまた自ずから別の問 題である。すなわち bond の結果として、一般に熱膨 脹特性の異なる材料が高温にて接着され冷却とともに生 ずる応力が、部品材料の強度特に普通材料的に最も弱い セラミックの強度を上廻る時は封着体が破壊し、あるい は (材料強度一封着応力) で示される封着体の強度が問 


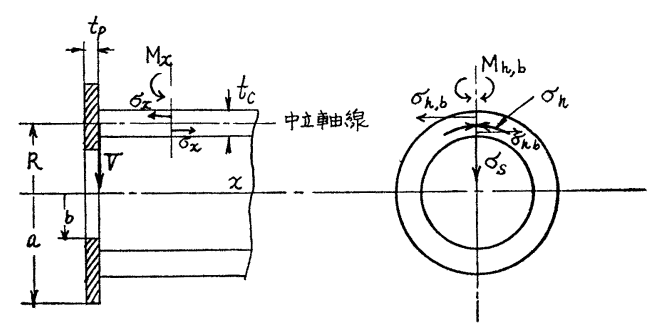

第 9 図 封着体に発生する応力

題となり、いわゆるシール材料のマッチングが重要な課 題となってくる。以下やはりわ市れの取扱った前还の 板封じ形態についてかような応力の内容を考察してみる こととしたい。

今、第 9 図のような封着形態で、金属板の熱膨脹がセラ ミックのそれよりも大きい時は、セラミック円筒の断面 には図に示したように半径方向に䡃く剪断応力 $\sigma_{\mathrm{s}}$ と円 周方向に働くタ力応力 (hoop stress) $\sigma_{\mathrm{h}}$, および曲け モーメント $M_{\mathrm{h}}, \mathrm{b}$ による応力 $\sigma_{\mathrm{h}}, \mathrm{b}$ が発生する。また軸 方向にも、その断面に動く曲げモーメント $M_{\mathrm{x}}$ により、 中立軸線を境とし内側と外側て方向が反対にして各表面 で最大となる折曲け応力 $\sigma_{\mathrm{x}}$ が発生する。 $\sigma_{\mathrm{h}}$ は締付応 力なので圧縮に強い（ $10 \times$ 単純引張強度）セラミック では考察の対象から除外てき、また $\sigma_{\mathrm{h}, \mathrm{b}}$ および $\sigma_{\mathrm{s}}$ は 通常かなり小さくなるので結局 $\sigma_{\mathrm{x}}$ についてのみ考光れ ばよい。

この応力を理論的に橄密に取扱うことは困難なので、 われわれは薄肉円筒理論 ${ }^{(19)}$ に基ずいた近似解析 ${ }^{(20)(21)}$ を行った。その結果第 9 四の封着体て

1）金属板の曲りに対する剛性が $\infty$ すなわ板が 全然曲らないとした場合発生応力が最大となり、

$$
x=0
$$

の点で、最大值

$$
\sigma_{x \max }, \infty=\frac{3 \cdot E_{\mathrm{c}} \Delta \varepsilon}{1.7+1.3 M \cdot \overline{S \cdot F_{D}}}
$$

となる。

2）金属板の曲りに対する剛性が 0 ，すなわち板が完 全に曲る場合発生応力は最小となり、

$$
x=\pi / 4 \beta
$$

の点で、最大值

$$
\sigma_{x \max , o}=\frac{1.93 \cdot E_{\mathrm{c}} \Delta \varepsilon}{3.5+1.3 M \cdot S \cdot F_{D}}
$$

となる。

上式て、 $E_{\mathrm{c}}$ ：セラミンクのヤング率。

$\Delta \varepsilon$ ：単位長さ当りの伸び差。

$M$ (材料係数) $=E_{c} / E_{p}$ 。

$E_{p}:$ 金属板のヤング率

$$
\begin{aligned}
& S(\text { 形认係数 })=\left[a^{2} / R^{2}\left(1+\mu_{p}\right)^{2}+\left(1-\mu^{2}\right)\right. \\
& \left.+a^{2} / b^{2}\left(1-\mu_{p}^{2}\right)+R^{2} / b^{2}\left(1-\mu_{p}\right)^{2}\right] \times \frac{1}{2\left(1-a^{2} / b^{2}\right)}
\end{aligned}
$$

$\mu_{p}:$ 金属板のポアソン比

$F_{D}($ 寸法係数 $)=t_{c}{ }^{3 / 2} / t_{p} R^{1 / 2}$

$\beta=\sqrt[4]{3\left(1-\mu_{c}^{2}\right) /\left(R^{2} t_{c}^{0}\right)}$

$\mu_{c}:$ セラミックのポアソン比

一般にはある曲りを伴ってこの中間の応力值を取るは ずであるが、通常の厚さの金属板ては曲けに対する剛性 がほとえど 0 となるのて、理論的には(2)の場合に相当す ることになる。第10図にこの応力值が軸方何に変化する

\begin{tabular}{|c|c|c|c|}
\hline & ヤンフ率E & ポアリン比 & 折曲け強度 \\
\hline$T_{i}$ & $1.09 \times 10^{6} \mathrm{~kg} / \mathrm{s}$ & 03 & \\
\hline アルミナ & $278 \times 10^{6}$ & 02 & $285^{\mathrm{kg} / \mathrm{mm}^{2}}$ \\
\hline
\end{tabular}
ようすを示した。この図预よび (1)，(3) 式から、板の曲り 剛性が $の$ 場合は最大応力の発生部が封着部となり、

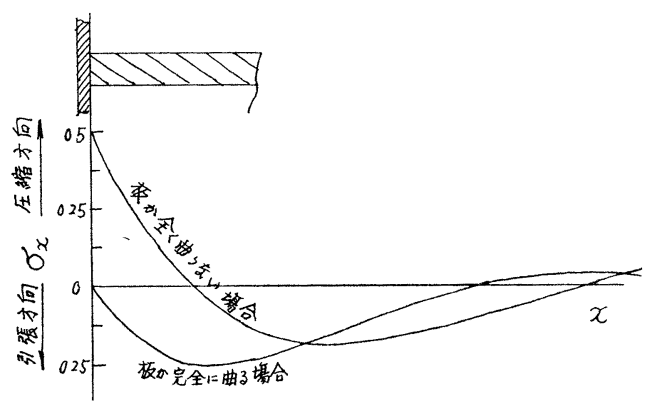

第 10 図 曲げモーメント $M_{x}$ により断面に働く 応力 $\sigma_{x}$ の $x$ 方向分布曲線

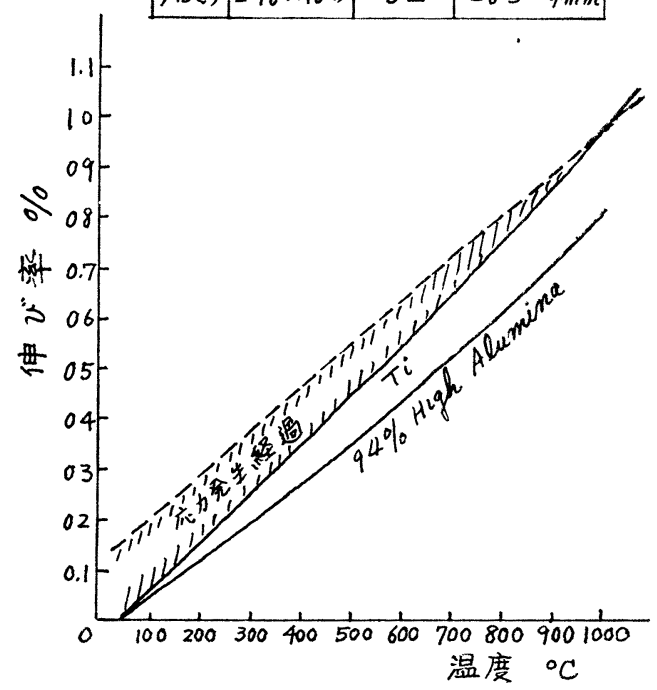

第 11 図 供試材料の熱膨脹特性と材料常数 
その近辺では外側に圧縮内側に引張り方向の応力が働 き、また0の場合には最大応力が封着部より離れた点に 西って外側に引張り応力が働くことがわかり、こ机は実 験的にも認好られる性質である。

上式で発生応力は封着温度に扝ける単位長当りの伸び 差に比例し、膨脹係数が直線的ならば

$$
\Delta \varepsilon=\left(\alpha_{p}-\alpha_{c}\right) \cdot\left(T_{\text {aeal }}-T_{\text {room }}\right)
$$

となるので金属・セラミックの膨脹俰数の差と封着温度 に比例することがわかり、先沉触れた材料のマッチング および封着温度が端的に影響することが示されており、 この関係はまた総べてのシール 形態に共通しているこ

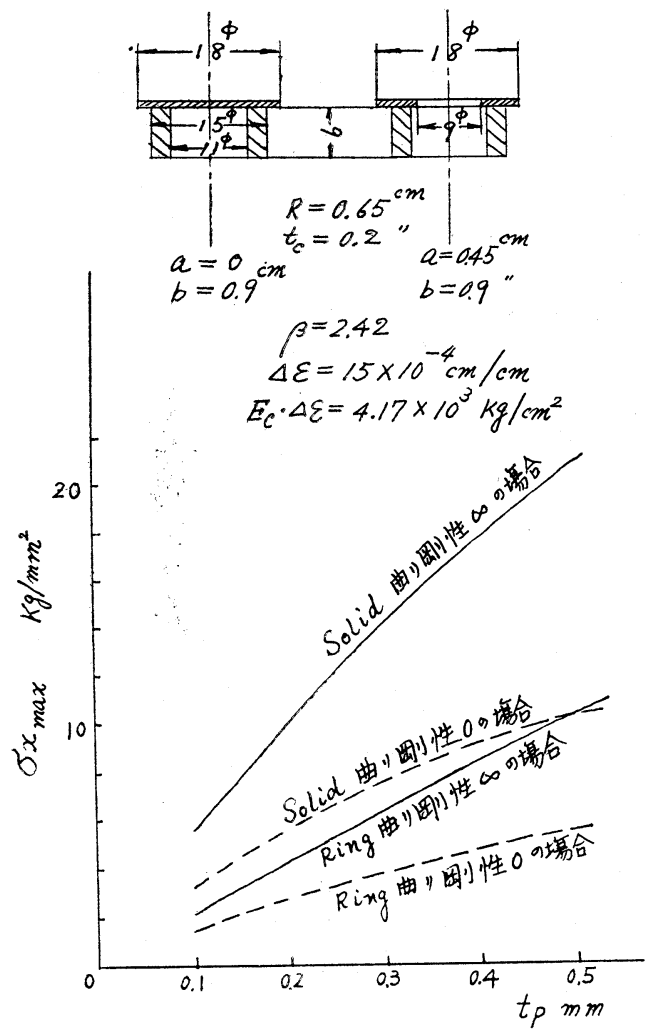

第12図 供試試料の応力計算值

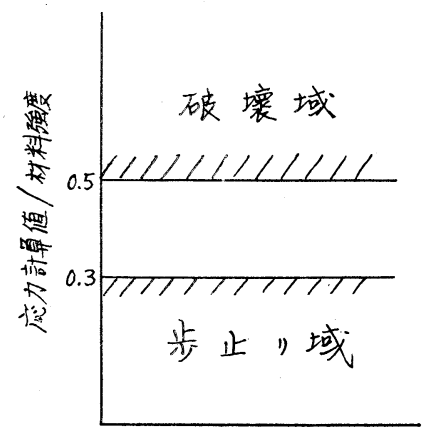

第13匈応力計算値と歩止りの関係
とが記憶されなければならない。部品寸法の撰定に際し ては、寸法係数 $F_{D}$ の形に見られるようにセラミックの 肉厚が最も効き、また分母子の 指数の和が一致するこ とと形状係数 $S$ の形からセラミック円筒の径と肉厚およ び金属板の形状寸法との間に相似則が成立つことがわか る。また金属板の両側に対称的に封着した場合について は、板の厚さを $1 / 2 に と り$ 曲り剛性' $\infty$ の場合の片面封じ として計算される。なお片面封着の場合、理論的には ほとえぞ曲り剛性 0 の場合となるはずであるが、のとの 中間值ないし大きめとする方が実験的事実に近いようで ある。

われわれの用いた第11図のごとき膨脹特性と常数を有 する材質について、(2)秥よび(4)式により第4 図の寸法の 封着体の発生応力を計算したものを、横軸に Ti 板の厚 さを取って第12図に示した。この計算値と実際の歩止り の間には第13図のような関係が忍められた。縦軸は計算 値と実測したセラミックの折曲げ強度の比である。すな わち上の計算式を利用し 3 以上の安全係数を取って設計 すれば大体良いととが示される。計算值とのこの開き は、計算に入らない鑞層の存在等種々の要素が考兄られ るが根本的には近似理論の適合度の問題となろう。

上記のような突合わせシールの形態は封着応力が大き くなるので、応力に関する限りできるだけ膨脹係数の大 きい金属を外側にした同心円筒型シールの採用が望まし い。また ductility の高い金属や鑞を使用し、あるいは 部品に可撓性を持たせた形状・寸法を採用するなど、 応力を軽減する種々の方法が考光られる。

第了表に American Lava Corp. のカタログに示され ている封着用セラミックの定数值を揭げておく。

\section{6. 封着体の強度}

前に述べたように、封着体の強度は論理的に残留強度 (ニセラミック材料強度一封着応力)で示され、なんらか の形でこ机を上廻る外力が重畳した時に破壞する。実用 上かような封着体に働く外力で最も問題となるのは熱的 な条件による外力、すなわち加熱による温度分布に伴っ て発生する熱応力でしかもしばしば衝撃性であることに よろう。そもそもセラミック・シールの耐熱性は、高温に おけるセラミック素材の形状維持性や化学的安定性また 真空管技術において重要なガス放出の少ないことなどの 面と上記のような熱応力に対する優れた性質の二面で示 されている。後者に当る耐熱衝撃性の増大には、残留強度 を大にする材質・設計值の選定が女げられるが、この他 に考慮すべきことは、普通実用上の場面で起る熱衝撃は 空気中などの気体雾囲気においてであり、この場合セラ ミックの熱伝導率が重要な因子になってくる(22)(23) こと 
第 3 表 封着用七ラミックの材料定数

\begin{tabular}{|c|c|c|c|c|}
\hline & 単 & $\begin{array}{c}\text { Forsterite } \\
2 \mathrm{MgO} \cdot \mathrm{SiO}_{2}\end{array}$ & $\begin{array}{c}\text { Zircon } \\
\mathrm{ZrO}_{2} \cdot \mathrm{SiO}_{2}\end{array}$ & $\begin{array}{c}\text { Alumina } \\
\mathrm{Al}_{2} \mathrm{O}_{3}\end{array}$ \\
\hline 吸 水 率 & $\%$ & $0-0.02$ & $0-0.02$ & $0-0.00$ \\
\hline 比重 & & 2.8 & 3.7 & 3.7 \\
\hline 軟 化 温 度 & ${ }^{\circ} \mathrm{C}$ & 1440 & 1440 & 1650 \\
\hline 連続加熱安全温度 & ${ }^{\circ} \mathrm{C}$ & 1000 & 1100 & 1550 \\
\hline モ一硬 度 & & 7.5 & 8 & 9 \\
\hline 熱 膨 脹 係 数 & $/{ }^{\circ} \mathrm{C} \begin{array}{l}\left(25-300^{\circ} \mathrm{C}\right) \\
\left(25-700^{\circ} \mathrm{C}\right)\end{array}$ & $\begin{array}{l}100 \times 10^{-7} \\
112 "\end{array}$ & $\begin{array}{l}44 \times 10^{-7} \\
41\end{array}$ & $\begin{array}{l}65 \times 10^{-7} \\
79\end{array}$ \\
\hline 引 張 強 度 & psi & 10,000 & 12,000 & 25,000 \\
\hline 圧 縮 強 度 & psi & 8,5000 & 100,000 & 400,000 \\
\hline 折曲 ゲ強度 & psi & 20,000 & 22,000 & 60,000 \\
\hline 絶 縁 耐 力 & $\mathrm{V} / \mathrm{mil}(60 \mathrm{c} / \mathrm{s})$ & 240 & 250 & 250 \\
\hline 体積固有 抵 抗 & $\begin{array}{r}\left(25^{\circ} \mathrm{C}\right) \\
\left(700^{\circ} \mathrm{C}\right)\end{array}$ & $\begin{array}{c}>10^{14} \\
1.0 \times 10^{9}\end{array}$ & $\begin{array}{r}>10^{14} \\
1.4 \times 10^{7} \\
\end{array}$ & $\begin{array}{l}>10^{14} \\
4.0 \times 10^{7}\end{array}$ \\
\hline 誘＼cjkstart電 & $\begin{aligned} 60 \mathrm{c} / \mathrm{s} \\
1 \mathrm{MC} \\
100 " \\
10,000 "\end{aligned}$ & $\begin{array}{l}6.3 \\
6.2 \\
6.1 \\
5.8\end{array}$ & $\begin{array}{l}9.1 \\
8.8 \\
8.6 \\
8.4\end{array}$ & $\overline{9 . \overline{3}}$ \\
\hline 力 $(\tan \delta)^{\text {率 }}$ & $\begin{array}{r}60 \mathrm{C} / \mathrm{S} \\
1 \mathrm{MC} \\
10,000 \mathrm{Mc}\end{array}$ & $\begin{array}{l}0.0014 \\
0.0004 \\
0.0010\end{array}$ & $\begin{array}{l}0.036 \\
0.0010 \\
0.0027\end{array}$ & $\begin{array}{l}-\overline{00} \\
0.003 \\
0.0014\end{array}$ \\
\hline 損 失 係 数 & $\begin{array}{r}60 \mathrm{C} / \mathrm{S} \\
1 \mathrm{MC} \\
10,000 \mathrm{MC}\end{array}$ & $\begin{array}{l}0.009 \\
0.002 \\
0,0058\end{array}$ & $\begin{array}{l}0.327 \\
0.009 \\
0.023\end{array}$ & $\begin{array}{l}0 . \overline{0} \\
0.0130\end{array}$ \\
\hline
\end{tabular}

第 4 表各種材料の熱径導特性

\begin{tabular}{|c|c|c|c|c|}
\hline 材 質 & $\begin{array}{c}K \text { (熱伝道率) } \\
\mathrm{Cal} / \mathrm{cm} /{ }^{\circ} \mathrm{C} / \mathrm{s} \mathrm{cm}{ }^{2}\end{array}$ & $\begin{array}{c}C \text { (比 熱) } \\
\mathrm{Cal} / \mathrm{g}^{\circ} \mathrm{C}\end{array}$ & $\rho$ (比重) & $\begin{array}{l}\text { 熱伝達係数 } \\
K / C \rho\end{array}$ \\
\hline アルミナ & 0.045 & 0.106 & 3.6 & 0.118 \\
\hline ベリリヤ & 0.135 & 0.299 & 3.0 & 0.152 \\
\hline 不 銹 鋼 & 0.039 & 0.12 & 8.6 & 0.038 \\
\hline チ タ ン & 0.041 & 0.13 & 4.5 & 0.070 \\
\hline 熔 融 石 英 & 0.0038 & 0.2 & 2.2 & 0.0087 \\
\hline 硼硅酸ガラス & 0.004 & 0.2 & 2.2 & 0.0091 \\
\hline ソーダガラス & 0.0022 & 0.2 & 2.5 & 0.0044 \\
\hline グラフアイト & 0.300 & 0.3 & 3.5 & 0.286 \\
\hline 銅 & 0.900 & 0.094 & 8.9 & 1.08 \\
\hline
\end{tabular}


である。その伝導率が不銹鋼や $\mathrm{Ti}$ よりも高いアルミナ や、さらに鉄よりも高いベリリヤ磁器がこの点で優れた シール材料と目される所以であろう。参考のため第 4 表 に諸材料の熱伝導常数值を比較して示した。

第 4 図の封着体は $800^{\circ} \mathrm{C}$ の電気炉中へ大気中より投 入し、均熱化したのち再び大気中に取出す衝撃試験や、 液体窒素 $\left(-195.7^{\circ} \mathrm{C}\right)$ 中に大気中より投入し、また取 出す試験に繰返えし10回以上堪光気密性が全く損われな いことが確められた。適当な封着強度を持つならば、そ の他のセラミック・シールに和いてもこれと同程度の耐 熱性を持つこともまた示されている。

\section{むすび}

$\mathrm{Ti}$ - Ni 活性合金法による板封じ技術を中心に、今 日もっとも実用されているメタライズ法と活性金属法の 2 系統についてそれぞれの技術の特色を比較しつつ解説 を行った。セラミック・シール技術は、金属とセラミッ クの化学的な結合反応をコントロールする技術と、封着 体に発生する応力を吟味し適切な材料と設計を選定する 技術とがその要素となっているが、細部においては個々 の条件に応じてその技術も極めて多彩化されている。セ ラミック・シールの目的とされる対象によって、これら のなかからもっとも適切な技術的方法が選ばれるべきで あり、さらにこれらが改良されて各方面にますます広く 活用されるようになることが期待される次第である。

[文 献〕

1) Electronics 33, [18] 55(1960)

2) Aviation Week 115 (May, 1959)

3 ) H. J. Nolte and R. F. Spurck : Television Eng. 1, [14] 14 (1950)
4）昭和 31 年電気通信学会全国大会シソポジウム予稿

5 ）三田他：東芝レビュー 13，217 (1958)

6 ) 中田他：日立評論別冊 34, 79 (1959)

7 ) Proceeding of The 3rd National Conference on Tube Techniques New York Uni. Press (1956)

8 ) R. J. Bondley : Electronics 20 [7] 97 (1947)

9 ) C. S, Pearsall and P. K. Zingeser : M. $I$. T. Tcch. Report NO.140 (1949)

10) H. Bender : Ceramic Age 53, [4] 15 (1954)

11) T.L. Evans : Ceramic Age 64, [2] (1954)

12）比留間他：通研成果報告 No. 957 (1956)

13) J. E. Beggs : I. R. E. Trans. CP-4, No. 1 (1957)

14) A. Taylor and R. W. Floyd : J. I. Metals 80, 577 (1952)

15) Poole and Hume-Rothery: J. I. Metals 83, 473 (1955)

16) S. S. Cole and F. J. Hynes : Am. Ceramic Soc. B. 37, [3] 135 (1958)

17) J. M. Lafferty : I. R. E. Trans. ED-5, No .3 (1958)

18）特許公報：昭 $35-13074$

19) S. Timoshenko : Theory of plates and Shells McGraw-Hill Co. (1938)

20）室松他：通研成果報告 No. 1328 (1959)

21）高木通泰：東芝レビェー9, [5]459（1954）

22) W. D. Kingery :J.Am. Ceramic. Soc. 38, [1] 2 (1955)

23) D. H. Preist and R. Talcott : Am. Ceramic Soc. B. 38, [3] 99 (1959) 